\title{
Clinical Case Study
}

\section{Hepatic Abscess due to Streptococcus anginosus and Eikenella corrodens, Secondary to Gastric Perforation by a Fish Bone}

\author{
Rita João Gonçalves ${ }^{a}$ António Murinellob Sílvia Gomes da Silvac \\ João Santos Coelho ${ }^{c}$ Adriana Lopes Santos ${ }^{b}$ Helena Sá Damásio ${ }^{b}$ \\ a Infectious Diseases Department, Hospital de Curry Cabral, Centro Hospitalar Universitário de Lisboa Central, \\ Lisbon, Portugal; ${ }^{b}$ Internal Medicine Department, Hospital de Curry Cabral, Centro Hospitalar Universitário de \\ Lisboa Central, Lisbon, Portugal; ' ${ }^{C}$ Hepatobiliary Surgery Department, Hospital de Curry Cabral, Centro Hospitalar \\ Universitário de Lisboa Central, Lisbon, Portugal
}

\section{Keywords}

Liver abscess · Fish bone · Streptococcus anginosus .

Eikenella corrodens

\section{Abstract}

Introduction: Foreign-body ingestion is a common event, but in only less than $1 \%$ of the cases complications occur. Hepatic abscesses induced by foreign-body penetration are rare. To date, there are only 62 reported cases of hepatic abscess secondary to fish bone perforation of the gastrointestinal tract. Case Presentation: A 78-year-old male patient was admitted due to high fever and vomiting for 2 days, along with frequent eructations for the past 3 months. Abdominal ultrasound showed a liver abscess in the left lobe, and computed tomography revealed a hyperdense linear image that crossed the superior wall of the gastric antrum, contacting the liver lesion, suggestive of a foreign body, probably a fish bone. Blood cultures were positive with isolation of Streptococcus anginosus and Eikenella corrodens. UItrasound-guided percutaneous drainage of the abscess was done, and S. anginosus was isolated in the pus. Surgical debridement and fish bone removal were performed; the patient completed 21 days of antibiotic therapy, with a favorable evolution. Conclusion: To the best of our knowledge, this is the first reported case of liver abscess caused by fish bone penetration with isolation of S. anginosus and E. corrodens. Bacterial coaggregation is one of the mechanisms that can explain their ability for causing invasive infections away from the oral cavity, by increasing their resistance to the innate immune system and survival of both species.

(c) 2019 Sociedade Portuguesa de Gastrenterologia Published by S. Karger AG, Basel

\section{Abcesso hepático por Streptococcus anginosus e Eikenella corrodens, secundário a perfuração gástrica por espinha de peixe}

\section{Palavras Chave}

Abcesso hepático $\cdot$ Espinha de peixe $\cdot$ Streptococcus anginosus · Eikenella corrodens

\section{Resumo}

Introdução: A ingestão de corpo estranho é frequente, mas em menos de $1 \%$ dos casos ocorrem complicações. Os abcessos hepáticos secundários a penetração por corpo estranho são muito raros. Até à data, estão reportados na literatura apenas 62 casos de abcesso hepático

\section{KARGER}

E-Mail karger@karger.com www.karger.com/pjg
(C) 2019 Sociedade Portuguesa de Gastrenterologia Published by S. Karger AG, Basel

Karger

Open access

This article is licensed under the Creative Commons AttributionNonCommercial-NoDerivatives 4.0 International License (CC BYNC-ND) (http://www.karger.com/Services/OpenAccessLicense) Usage and distribution for commercial purposes as well as any distribution of modified material requires written permission.
Rita João Gonçalves

Infectious Diseases Department

Hospital de Curry Cabral, Centro Hospitalar Universitário de Lisboa Central

Rua da Beneficência, no 8, PT-1069-166 Lisbon (Portugal)

E-Mail rita.joao.goncalves@gmail.com 
secundário a perfuração do tracto gastrintestinal por espinha de peixe. Caso clínico: Um homem de 78 anos foi internado por quadro de febre alta e vómitos com dois dias de evolução, a par de eructações frequentes nos últimos três meses. A ecografia abdominal revelou abcesso hepático no lobo esquerdo e a tomografia computorizada demonstrou imagem hiperdensa linear, contactando a lesão hepática e atravessando a parede superior do antro gástrico, sugestiva de corpo estranho (espinha de peixe). As hemoculturas foram positivas com isolamento de Streptococcus anginosus e Eikenella corrodens. O abcesso foi drenado por punção aspirativa eco-guiada, isolandose Streptococcus anginosus no exsudado purulento. Realizou desbridamento cirúrgico e remoção da espinha; completou 21 dias de antibioterapia, com evolução favorável. Conclusão: Após revisão da literatura, este é o primeiro caso descrito de abcesso hepático secundário a perfuração por espinha de peixe, por Streptococcus anginosus e Eikenella corrodens. Um dos mecanismos que explica o seu potencial para causar infecções invasivas e distantes da cavidade oral é a coagregação bacteriana que contribui para a maior resistência ao sistema imunológico inato do hospedeiro e aumento da sobrevivência das duas espécies. @ 2019 Sociedade Portuguesa de Gastrenterologia Publicado por S. Karger AG, Basel

\section{Introduction}

Pyogenic hepatic abscesses are suppurative infections due to bacterial invasion of the liver parenchyma. They are classified by the routes of hepatic invasion, which can happen through the biliary tree, the portal vein, the hepatic artery, through direct extension from a contiguous site of infection or trauma. Hepatic abscesses due to trauma inflicted to the liver are rare, accounting for $0-5 \%$ of the cases [1]. From these, the ones caused by penetrating trauma due to gastrointestinal perforation by an ingested foreign body are even less common. It is a serious condition that can be fatal if not timely recognized and treated [2]. When it occurs, the perforating agents most frequently found are fish bones [3, 4], with 62 cases described in the world literature to date, followed by other sharp objects such as chicken bones, toothpicks or needles. The microorganisms isolated are usually part of the normal flora of the oropharynx [3].

The authors present a case of liver abscess caused by Streptococcus anginosus and Eikenella corrodens secondary to a fish bone gastric perforation and penetrating trauma to the liver.

S. anginosus and E. corrodens Hepatic

Abscess Secondary to Fish Bone

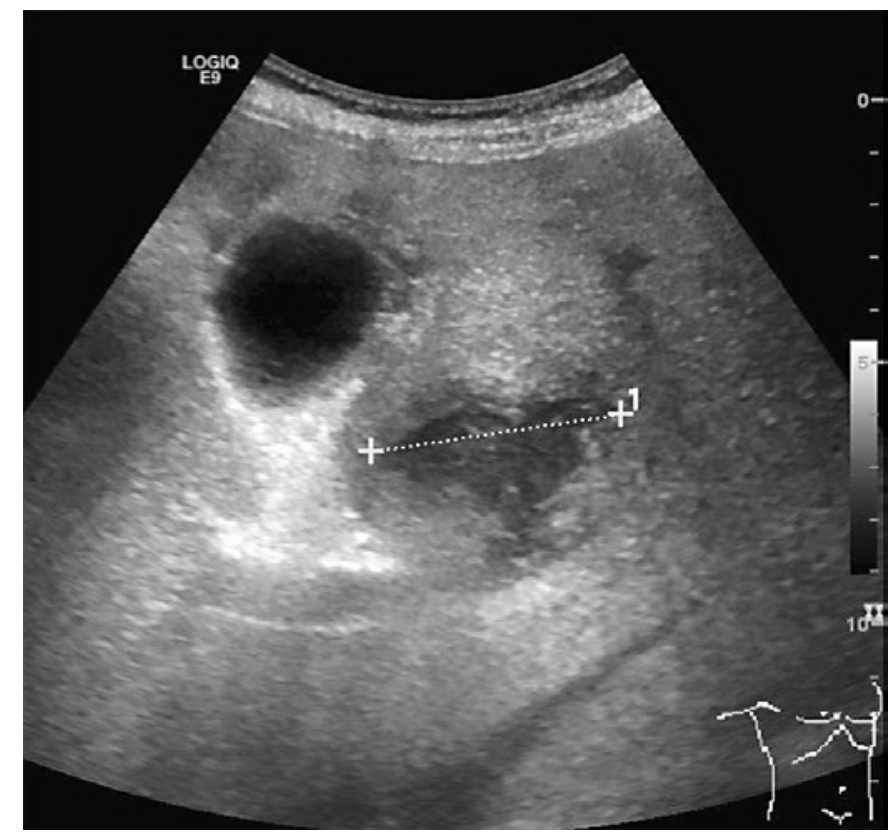

Fig. 1. Abdominal ultrasound: hepatic abscess, $4.5 \mathrm{~cm}$ in diameter, in segment IVb.

\section{Case Presentation}

A 78-year-old male patient presented to the emergency department complaining of high fever $\left(39.5^{\circ} \mathrm{C}\right)$ and chills, somnolence, nausea and vomiting, for 2 days. He also mentioned frequent eructations in the past 3 months, with no correlation with food ingestion.

At physical examination he was febrile $\left(38.9^{\circ} \mathrm{C}\right)$, blood pressure was $108 / 65 \mathrm{~mm} \mathrm{Hg}$, heart rate was 116 beats/min, respiratory rate was 26 breaths/min and oxygen peripheral saturation was $85 \%$ in ambient air. He was somnolent but oriented, and his oral mucosa was dehydrated. His oral hygiene was adequate; he used a dental prosthesis on the upper maxillary arcade and had no visible dental cavities. Heart and respiratory sounds were normal. Abdominal palpation was painless but with hepatomegaly $4 \mathrm{~cm}$ below the costal margin. The rest of the examination was unremarkable.

The patient had a known history of type 2 diabetes mellitus, well controlled with oral therapy, hypercholesterolemia, colic diverticulosis and benign colic polyps excised 3 years before, benign prostate hypertrophy and a corneal transplant 20 years back following trauma in a car accident. He had no alcohol, smoking or drug habits.

His arterial blood gas sample without oxygen support was as follows: $\mathrm{pH}$ 7.49; $\mathrm{pCO}_{2} 22 \mathrm{~mm} \mathrm{Hg} ; \mathrm{pO}_{2} 51 \mathrm{~mm} \mathrm{Hg} ; \mathrm{HCO}_{3} 16 \mathrm{~mm}$ $\mathrm{Hg}$; lactate $5.5 \mathrm{mmol} / \mathrm{L}$.

Laboratory evaluation showed: hemoglobin $14.1 \mathrm{~g} / \mathrm{dL}$; leukocytes $6.70 \times 10^{9} / \mathrm{L}$, neutrophils $98 \%$; platelets $288 \times 10^{9} / \mathrm{L}$; prothrombin time $63 \%(70-130 \%)$, spontaneous international normalized ratio $1.32(0.8-1.20)$; aspartate aminotransferase $329 \mathrm{U} / \mathrm{L}(<50)$; alanine aminotransferase $202 \mathrm{U} / \mathrm{L}(<50) ; \gamma$-glutamyltransferase $49 \mathrm{U} / \mathrm{L}(<55)$; alkaline phosphatase $335 \mathrm{U} / \mathrm{L}$ 

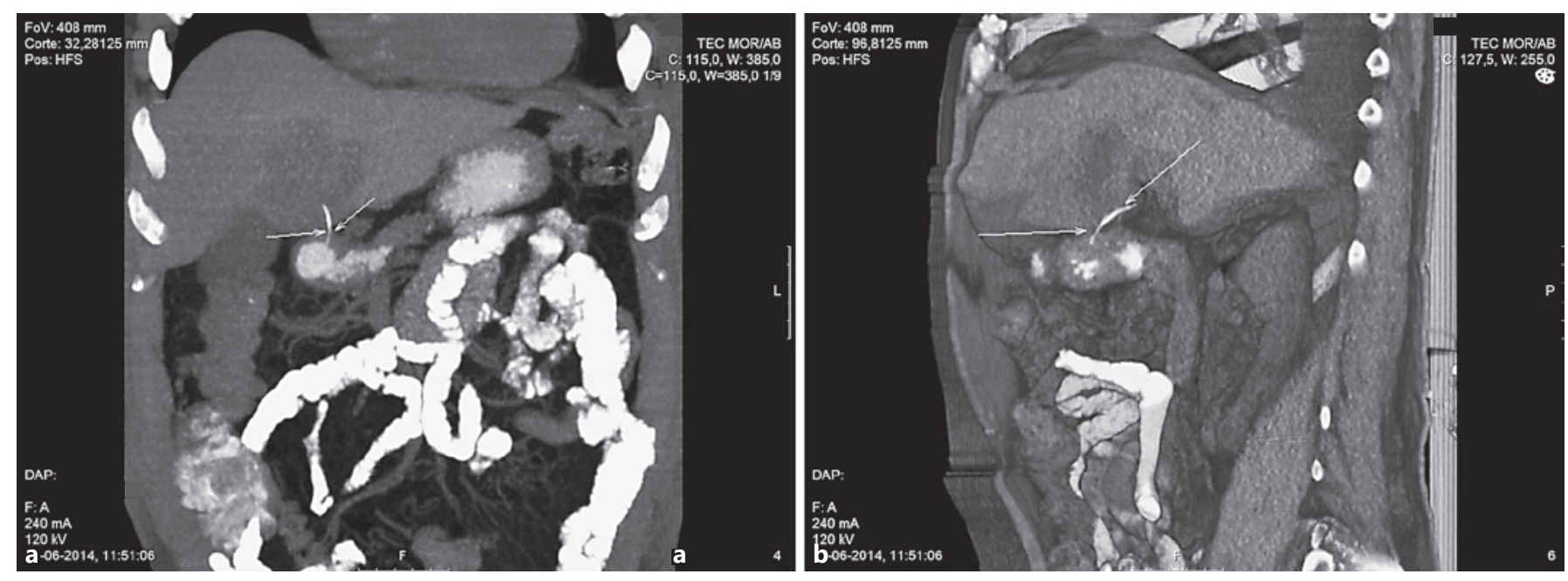

Fig. 2. Abdominal CT scan: hypodense lesion in segment IVb $(64 \times 40 \times 44 \mathrm{~mm})$, suggestive of liver abscess. Hyperdense linear image $35 \mathrm{~mm}$ long that crossed the superior wall of the gastric antrum, contacting the liver lesion, suggestive of a foreign body, probably a fish bone. a Coronal view. b Sagittal view.

(30-120); total bilirubin $0.86 \mathrm{mg} / \mathrm{dL}(0.3-1.2)$; urea $54 \mathrm{mg} / \mathrm{dL}$ (18-55); creatinine $2.07 \mathrm{mg} / \mathrm{dL}(0.67-1.17)$; lactate dehydrogenase $620 \mathrm{U} / \mathrm{L}(<248)$; glucose $234 \mathrm{mg} / \mathrm{dL}$ (60-100); C-reactive protein $425.5 \mathrm{mg} / \mathrm{L}(<5.0)$. HIV, HBV, HCV and VDRL serologies were negative. Urine sediment was normal, chest radiography showed no pathological signs. Abdominal ultrasound revealed an image suggestive of a liver abscess $(4.5 \mathrm{~cm})$ in the left lobe (segment IVb) (Fig. 1).

After collecting blood cultures, he started empiric antibiotic therapy with piperacillin-tazobactam and metronidazole, and he was admitted to the ward.

An urgent abdominal computed tomography (CT) scan was done, which showed a hypodense lesion in the segment IVb $(64 \times$ $40 \times 44 \mathrm{~mm}$ ), suggestive of liver abscess. In addition, it revealed a hyperdense linear image $35 \mathrm{~mm}$ long that crossed the superior wall of the gastric antrum, contacting the liver lesion, suggestive of a foreign body, probably a fish bone (Fig. 2a, b). He had also a small quantity of ascites and small bilateral pleural effusion.

An ultrasound-guided percutaneous drainage of the abscess was performed, and the pus was sent for microbiological analysis (Fig. 3). Surgical drainage was done, through median laparotomy, and an adherence of the pylorus to the liver (segment IV b) was seen, covered by the lesser omentum, containing the abscess. At exploration, a foreign body compatible with a fish bone was detected and removed (Fig. 4). The abscess, with $6 \mathrm{~cm}$, was debrided and washed. A pyloric perforation test with methylene blue was made, showing no signs of extravasion. An omentoplasty was done at the pylorus level, and a Jackson-Pratt drain was left on the abscess site. No complications were noticed in the postsurgery period. Later in the course of the admission, the patient recalled having swallowed a fish bone from a red porgy (Pagrus pagrus) exactly 3 months before.

$S$. anginosus sensitive to penicillin was isolated in two blood cultures and in the pus drained from the liver abscess. Moreover, E. corrodens was isolated also in one blood culture. An echocardiogram excluded infective endocarditis. The patient was treated for

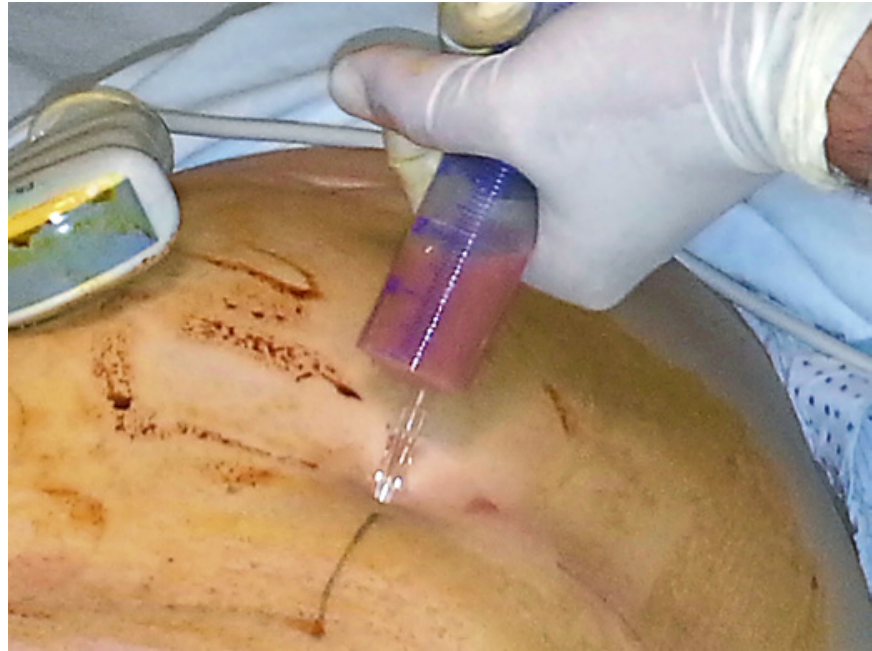

Fig. 3. Ultrasound-guided percutaneous drainage of the abscess.

14 days with piperacillin/tazobactam and metronidazole intravenously, after which he was discharged. He continued therapy for 7 more days with amoxicillin-clavulanate, orally. His follow-up for the next 4 years was unremarkable.

\section{Discussion/Conclusion}

Foreign-body ingestion, including fish bones, is a common event. Most patients have an uneventful course. Only in less than $1 \%$ of the cases do complications occur, 
such as gastrointestinal perforation [5]. Perforation can occur at any site of the gastrointestinal tract, but regions of acute angulation such as the ileocecal and rectosigmoid regions appear to be the most common affected $[5,6]$. Hepatic abscess development following gastrointestinal perforation is even rarer [7].

In elderly patients, poor dentition or neurologic disorders can make the oral cavity digestion phase difficult and more prone to accidental events such as foreign-body ingestion [8]. Additionally, the wearing of dentures is a well-described risk factor for foreign-body ingestion, as it eliminates the tactile sensation of the palatal surface [5].

Streptococcus anginosus belongs to the $S$. anginosus group (SAG), which includes the species $S$. anginosus, $S$. constellatus and $S$. intermedius. They are commensals of mucosal membranes and are frequently found in the oral cavity, gastrointestinal tract, urogenital tract and are often implicated in abscess formation. These species form small colonies on blood agar plates and have a characteristic butterscotch smell. However, they display a very inconsistent phenotype regarding $\beta$-hemolysis and Lancefield antigens $[1,9]$. Some of the virulence factors of $S$. anginosus have been studied, such as adhesins [9] that allow the colonization of the oral cavity and the participation in the dental plaque's biofilm formation $[10,11]$, as well as its capacity to bind to extracellular matrix proteins [9]. Coaggregation, a process by which genetically distinct bacteria become attached to each other via specific molecules [10], appears to play also an important role in pathogenicity $[9,10]$. Interestingly, one of the bacteria studied for coaggregation with the SAG is E. corrodens [12], which has also been detected in mixed local infections with the SAG [13-15]. Although coaggregation occurred frequently, this did not stimulate growth of $S$. anginosus [12], indicating that both species may somehow benefit from coaggregation, probably through improved survival and increased resistance against the host innate immune system $[9,16]$.

Eikenella corrodens is a fastidious facultative anaerobic gram-negative bacillus that is part of the commensal microbiota of the mouth, upper respiratory tract, gastrointestinal and genitourinary mucosal surfaces. Eikenella infections are generally indolent in course and can mimic an anaerobic process due to the induction of foul-smelling suppuration $[1,17]$. It needs incubation in an atmosphere rich in $\mathrm{CO}_{2}$ for recovery in culture and has a predilection for causing endocarditis [1]. Eikenella grows slowly, normally taking 2 days or more to be recognized [1]. In fact, in our case, we could witness that the isolation and identification of this organism occurred after 5 days,

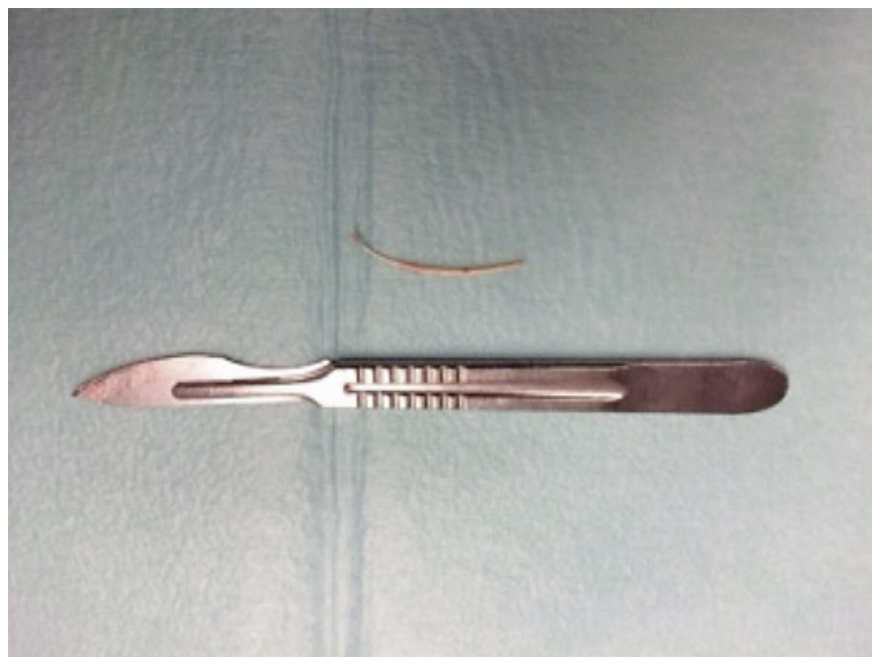

Fig. 4. Fish bone removed surgically.

2 days later than the identification of the S. anginosus. Head and neck are the most common sites of Eikenella infections but it can spread hematogenously following teeth brushing or procedures and cause extraoral infectious $[1,17]$. Most often, it is isolated as a component of polymicrobial infection, usually with other oral bacteria, particularly streptococci [17]. Rarely it has been the cause of visceral abscesses. It was only reported 13 times as a cause of intrahepatic abscess $[13,18]$. Generally, E. corrodens is susceptible to $\beta$-lactam antibiotics, tetracyclines and quinolones, but uniformly resistant to clindamycin, erythromycin, metronidazole and often resistant to aminoglycosides [1].

To the best of our knowledge this is the first reported case of liver abscess caused by fish bone penetration, with isolation of $S$. anginosus and E. corrodens. Notably, in only 3 cases reported of having liver abscess $[13,15,19]$ was there a similar association: Nagesh et al. (1977) [19] reported a liver abscess caused by a-hemolytic Streptococcus not groupable under Lancefield A, B or D and E. corrodens; Quinlivan et al. (1996) [13] reported a liver abscess caused by Streptococcus milleri (former designation of SAG) and E. corrodens; Chang et al (1999) [15] reported the same caused by E. corrodens, Streptococcus constellatus (part of SAG) and Bacteroides fragilis. These cases were not caused by penetrating trauma to the liver. Moreover, there is only one report of E. corrodens (singleagent) liver abscess caused by fishbone perforation of the gastrointestinal tract [20]. 
In our case, we consider that the source of both the bacteremia and the liver abscess was the gastric perforation by the fish bone that migrated, colonized by the two commensals of the oropharynx. The probable reason for the isolation of both microorganisms in blood cultures and only $S$. anginosus in the abscess pus is the medium into which the samples were collected: the profound aspirated pus from the abscess was sent for aerobic culture but it was not possible to send it in the preferred transport medium for anaerobic agents (Portagerm ${ }^{\mathrm{TM}}$ ). By contrast, the blood samples were collected to two pairs of aerobic and anaerobic mediums (BACT/ALERT ${ }^{\circledR}$ FA Plus and BACT/ALERT ${ }^{\circledR}$ FN Plus), with the latter allowing the growth of E. corrodens.

Diagnosis of this entity is challenging. A high clinical suspicion is paramount because complaints are nonspecific, and most patients do not recall the foreign-body ingestion $[3,4,21]$. There is sometimes a time lag of weeks to months between the ingestion and the onset of symptoms [7]. Moreover, plain radiography has only $32 \%$ sensitivity for detecting an ingested fish bone, because the radiopacity of the fish bone depends on the species of the fish [22]. CT has a higher sensitivity, showing typically a linear calcified lesion surrounded by an area of inflammation $[7,23]$. However, the faint calcification of a fish bone may be obscured by oral contrast, and when intravenous contrast is given the fish bone may mimic a small blood vessel and be overlooked [23]. Blood cultures and deep aspirated pus should always be sent for both aerobic and anaerobic cultures.

The treatment of choice for foreign-body liver abscesses includes a combination of percutaneous or surgical (laparotomy or laparoscopy [24]) drainage, removal of foreign body and repair of the perforation site, and antibiotics. Foreign-body removal is important to avoid further recurrence of the abscess $[22,25]$.

In conclusion, this case illustrates the possible multifactorial etiology of a liver abscess caused by fish bone penetration due to $S$. anginosus and E. corrodens. Firstly, the predisposing factors of the host: the dental prosthesis on the upper maxillary arcade enabled him to swallow the fish bone unnoticed, and type 2 diabetes mellitus could have predisposed him to have an invasive bacterial infection. Secondly, the mixed infection may be explained by the coaggregation between the two organisms, functioning as a pathogenic mechanism to allow their joint migration along with the fish bone and focalization away from the oral cavity. Lastly, it shows that a high suspicion and a timely response with early antibiotic therapy and an effective drainage lead to very good results even in the elderly patient with several comorbidities.

\section{Acknowledgment}

We would like to thank Dr. Lucinda Bogalho (Radiology Department), who performed the first CT, describing the first suspicion of the presence of a fish bone; as well as Dr. Nuno Carrilho Ribeiro (Radiology Department), who performed the ultrasound in the emergency department as well as the ultrasound-guided percutaneous drainage of the abscess.

\section{Statement of Ethics}

Written informed consent was obtained from the patient for publication of this case report with accompanying images.

\section{Disclosure Statement}

The authors have no conflicts of interest to declare.

\section{Funding Sources}

This research received no specific grant from any funding agency in the public, commercial or not-for-profit sectors.

\section{Author Contributions}

All authors have made contributions in the patient's observation, workup and treatment in medicine or surgical wards. R.J.G. performed the literature review and drafted the manuscript. A.M. provided senior guidance in manuscript writing, assisted in literature search and review and critically reviewed the manuscript for important intellectual content. S.G.S. continued patient follow-up for the following 4 years. All authors read and approved the version to be submitted.

References

1 Bennett JE, Dolin R, Blaser MJ. Mandell, Douglas, and Bennett's Principles and Practice of Infectious Diseases. Eight edition. Philadelphia: Elsevier-Saunders; 2014.

2 Theodoropoulou A, Roussomoustakaki M, Michalodimitrakis MN, Kanaki C, Kouroumalis EA. Fatal hepatic abscess caused by a fish bone. Lancet. 2002 Mar;359(9310):977.

3 Santos SA, Alberto SC, Cruz E, Pires E, Figueira T, Coimbra E, et al. Hepatic abscess induced by foreign body: case report and literature review. World J Gastroenterol. 2007 Mar;13(9):1466-70.

4 Leggieri N, Marques-Vidal P, Cerwenka H, Denys A, Dorta G, Moutardier V, et al. Migrated foreign body liver abscess: illustrative case report, systematic review, and proposed diagnostic algorithm. Medicine (Baltimore). 2010 Mar;89(2):85-95. 
5 Goh BK, Chow PK, Quah HM, Ong HS, Eu KW, Ooi LL, et al. Perforation of the gastrointestinal tract secondary to ingestion of foreign bodies. World J Surg. 2006 Mar;30(3): 372-7.

6 Matrella F, Lhuaire M, Piardi T, Dokmak S, Bruno O, Maestraggi Q, et al. Liver hilar abscesses secondary to gastrointestinal perforation by ingested fish bones: surgical management of two cases. Hepatobiliary Surg Nutr. 2014 Jun;3(3):156-62.

7 Goh BK, Tan YM, Lin SE, Chow PK, Cheah FK, Ooi LL, et al. CT in the preoperative diagnosis of fish bone perforation of the gastrointestinal tract. AJR Am J Roentgenol. 2006 Sep; 187(3):710-4.

8 Chen M, Lin H, Foo NP, Chen K. Fish bone penetration of the duodenum: a rare cause of liver abscess. Int J Gerontol. 2013;7(1):54-6.

9 Asam D, Spellerberg B. Molecular pathogenicity of Streptococcus anginosus. Mol Oral Microbiol. 2014 Aug;29(4):145-55.

10 Rickard AH, Gilbert P, High NJ, Kolenbrander PE, Handley PS. Bacterial coaggregation: an integral process in the development of multi-species biofilms. Trends Microbiol. 2003 Feb;11(2):94-100.

11 Kolenbrander PE, Andersen RN, Blehert DS, Egland PG, Foster JS, Palmer RJ Jr. Communication among oral bacteria. Microbiol Mol Biol Rev. 2002 Sep;66(3):486-505.
12 Young KA, Allaker RP, Hardie JM, Whiley RA. Interactions between Eikenella corrodens and 'Streptococcus milleri-group' organisms: possible mechanisms of pathogenicity in mixed infections. Antonie van Leeuwenhoek. 1996 May;69(4):371-3.

13 Quinlivan D, Davis TM, Daly FJ, Darragh H. Hepatic abscess due to Eikenella corrodens and Streptococcus milleri: implications for antibiotic therapy. J Infect. 1996 Jul;33(1):478

14 Jacobs JA, Algie GD, Sie GH, Stobberingh EE. Association between Eikenella corrodens and streptococci. Clin Infect Dis. 1993 Jan;16(1): 173.

15 Chang PS, Ni YH, Lin WT, Lee CY, Chang $\mathrm{MH}$. Isolation of Eikenella corrodens from polymicrobial hepatic abscess: report of one case. Acta Paediatr Taiwan. 1999 Jan-Feb; 40(1):50-2.

16 Ochiai K, Kurita-Ochiai T, Kamino Y, Ikeda T. Effect of co-aggregation on the pathogenicity of oral bacteria. J Med Microbiol. 1993 Sep; 39(3): 183-90.

17 Stein A, Teysseire N, Capobianco C, Bricot R Raoult D. Eikenella corrodens, a rare cause of pancreatic abscess: two case reports and review. Clin Infect Dis. 1993 Aug;17(2):273-5.

18 Nordholm AC, Vøgg RO, Permin H, Katzenstein T. Eikenella corrodens endocarditis and liver abscess in a previously healthy male, a case report. BMC Infect Dis. 2018 Jan;18(1): 35.
19 Nagesh KG, Poulose KP, Rao GM. Liver abscess: eikenella corrodens and streptococci. J Kans Med Soc. 1977 Jul;78(7):340-2.

20 Kessler AT, Kourtis AP. Images in clinical medicine. Liver abscess due to Eikenella corrodens from a fishbone. N Engl J Med. 2001 Dec;345(23):e5.

21 Bandeira-de-Mello RG, Bondar G, Schneider E, Wiener-Stensmann IC, Gressler JB, Kruel CR. Pyogenic Liver Abscess Secondary to Foreign Body (Fish Bone) Treated by Laparoscopy: A Case Report. Ann Hepatol. 2018 JanFeb;17(1):169-73.

22 Clarençon F, Scatton O, Bruguière E, Silvera $S$, Afanou G, Soubrane O, et al. Recurrent liver abscess secondary to ingested fish bone migration: report of a case. Surg Today. 2008; 38(6):572-5.

23 Bathla G, Teo LL, Dhanda S. Pictorial essay: complications of a swallowed fish bone. Indian J Radiol Imaging. 2011 Jan;21(1):63-8.

24 Panebianco A, Lozito RC, Prestera A, Ialongo P, Volpi A, Carbotta G, et al. Unusual liver abscess secondary to ingested foreign body: laparoscopic management. G Chir. 2015 MarApr;36(2):74-5.

25 Nisbet M, Thomas M, Mackowiak PA. Liver abscess associated with persistent Streptococcus anginosus bacteremia. Clin Infect Dis. 2005 Aug;41(3):352-3. 